\title{
PEMODELAN ARIMA INTERVENSI MULTI-INPUT UNTUK ANALISIS DAMPAK BENCANA TERHADAP KUNJUNGAN WISATAWAN MANCANEGARA KE PROVINSI BALI DAN NTB
}

\author{
(MULTI INPUT INTERVENTION MODEL FOR ANALYZE THE IMPACT OF DISASTER ON \\ TOURIST ARRIVALS TO PROVINCE BALI AND NTB)
}

\author{
Evita Dyah Wardhani ${ }^{1}$ \\ Politeknik Statistika STIS ${ }^{1}$ \\ E-mail: evitadyahw@gmail.com
}

\begin{abstract}
ABSTRAK
Potensi pariwisata di Indonesia yang mengagumkan membuat pemerintah ingin memanfaatkannya dengan baik, salah satunya untuk menunjang perekonomian negara. Salah satu alasan pemerintah memberikan perhatian besar dan dorongan untuk pengembangan sektor pariwisata karena pariwisata sebagai salah satu sektor penyumbang devisa terbesar. Hal ini berarti bahwa pemerintah ingin terus meningkatkan kunjungan wisatawan mancanegara agar penerimaan devisa juga meningkat. Provinsi Bali dan NTB merupakan dua dari beberapa daerah yang menjadi tujuan favorit wisatawan mancanegara. Namun, potensi pariwisata yang dimiliki Bali dan NTB terancam dengan bencana-bencana yang melanda kedua daerah tersebut. Beberapa bencana yang telah terjadi tahun 2010-2019 yaitu, erupsi Gunung Rinjani, erupsi Gunung Agung dan Gempa Lombok. Bencana tersebut diduga berdampak terhadap kunjungan wisatawan mancanegara. Penelitian ini bertujuan untuk melihat gambaran umum serta mengetahui dampak bencana terhadap kunjungan wisatawan mancanegara ke Indonesia. Analisis ARIMA intervensi digunakan pada penelitian ini untuk menjawab tujuan tersebut. Hasil pengujian menunjukkan bahwa erupsi Gunung Rinjani dan Gempa Lombok berdampak signifikan terhadap kunjungan wisatawan mancanegara ke Bali dan NTB, sedangkan erupsi Gunung Agung hanya berdampak terhadap kunjungan wisatawan mancanegara ke Bali. Dampak bencana paling besar dirasakan di Provinsi NTB saat Gempa Lombok.
\end{abstract}

Kata kunci: ARIMA, Intervensi, Bencana, Pariwisata

\section{ABSTRACT}

Indonesia's amazing tourism potential makes the government want to make good use of it, one of which is to support the country's economy. One of the reasons the government pays great attention and develops the tourism sector because it is one of the largest foreign exchange contributors. This means that the government wants to continue to increase foreign tourist visits so that foreign exchange earnings also increase. The provinces of Bali and NTB are two of several areas that are favorite destinations for foreign tourists. However, the tourism potential of Bali and NTB was disastrous with disasters that hit both areas. Some of the disasters that have occurred in 2010-2019 are the eruption of Mount Rinjani, the eruption of Mount Agung and the Earthquake of Lombok. The disaster is thought to have an impact on foreign tourist visits. This study aims to see the general description and disasters of natural disasters. ARIMA analysis of these interventions is used in this study to answer these objectives. The test results show that the eruption of Mount Rinjani and the Lombok Earthquake had a significant impact on foreign tourist visits to Bali and NTB, while the eruption of Mount Agung only had an impact on foreign tourist visits to Bali. The impact of the disaster felt in NTB Province during the Lombok Earthquake.

Keywords: ARIMA, Intervention, Disaster, Tourism

\section{PENDAHULUAN}

Potensi Pariwisata di Negara Indonesia sudah tidak diragukan lagi. Potensi ini tidak hanya disebabkan oleh alam akan tetapi juga karena budaya Indonesia yang kaya. Data Sensus Penduduk 2010 menyebutkan bahwa Indonesia memiliki 1.340 suku bangsa. Letak Indonesia yang strategis , yaitu diapit dua benua dan dua samudera membuat Pariwisata Indonesia tidak hanya terkenal di nusantara akan tetapi sudah dikenal di level Internasional. Bahkan Pada Tahun 2018 salah satu media besar dunia (Majalah Lonely Planet) menyebutkan bahwa Indonesia menduduki peringkat ke tujuh untuk kunjungan pariwisata terbaik (Hulwa, 2018). 
Besarnya potensi pariwisata yang dimiliki Indonesia membuat pemerintah ingin memanfaatkan itu dengan baik, salah satunya untuk menunjang perekonomian negara. Berbagai hal diupayakan pemerintah untuk mewujudkannya, salah satunya dengan mencanangkan sektor ini dalam Undang-undang Nomor 10 Tahun 2009 tentang Kepariwisataan. Salah satu tujuannya adalah mengurangi pengangguran yang sudah nampak keberhasilannya. Tahun 2015 hingga 2018 proporsi tenaga kerja industri pariwisata terhadap total pekerja terus mengalami kenaikan dan pada Tahun 2018 mencapai 11,17 persen.

Keadaan pariwisata Indonesia yang mengagumkan ini menjadi daya tarik wisatawan mancanegara sehingga kunjungan dari tahun ke tahun mengalami peningkatan yang otomatis akan menambah penerimaan devisa negara. Provinsi Bali dan NTB merupakan dua dari beberapa daerah yang menjadi tujuan favorit wisatawan mancanegara. Hal ini diakui juga oleh situs wisata terbesar di dunia yaitu TripAdvisor, yang mana kedua daerah tersebut mendapatkan penghargaan sebagai pulau dengan tujuan wisata terbaik se-Asia (Agmasari, 2016). Tidak mengherankan jika dari tahun ke tahun, Bali dan NTB memberikan sumbangan kunjungan wisatawan mancanegara ke Indonesia yang terus meningkat. Bahkan di Tahun 2016, kunjungan wisatawan mancanegara ke Bali dan NTB mencapai 55\% dari total wisatawan mancanegara yang ke Indonesia.

Namun, potensi pariwisata yang dimiliki Bali dan NTB terancam dengan bencana-bencana yang melanda kedua daerah tersebut. Gunung Agung dan Gunung Rinjani yang aktif dapat meletus kapan saja. Selain itu, Rahmat Triyono mengatakan bahwa kedua wilayah tersebut juga mendapat ancaman terjadinya gempa megathrust (Iman, 2019). Keadaan ini tentu menjadi ancaman bagi keberlangsungan pariwisata, karena kunjungan wisatawan asing sangat dipengaruhi oleh kondisi sosial politik, stabilitas keamanan di Indonesia dan juga dipengaruhi oleh berbagai bencana alam yang terjadi di Indonesia (Sudarmo, 2005). Beberapa bencana yang telah terjadi dan diduga memengaruhi kunjungan wisatawan mancanegara adalah Erupsi Gunung Rinjani, Erupsi Gunung Agung, dan Gempa Lombok.

Dampak dari bencana alam terhadap kunjungan wisatawan sudah banyak diteliti di berbagai negara. Penelitian yang dilakukan oleh (Huang \& Min, 2002) yang berjudul Earthquake devastation and recovery in tourism: the Taiwan case menerapkan metode peramalan dengan SARIMA untuk melihat pemulihan kedatangan wisatawan setelah gempa. Penelitian tersebut menghasilkan bahwa bencana gempa menyebabkan penurunan pada kunjungan wisatawan dan baru kembali pulih setelah 11 bulan. Hasil penelitian tersebut tidak berbeda dengan penelitian yang dilakukan oleh (Wu \& Hayashi, 2014). Penelitian yang berjudul The Impact of Disasters on Japan's Inbound Tourism Demand dengan metode ARIMA Intervensi menghasilkan bahwa bencana besar seperti wabah penyakit dan gempa bumi berpengaruh negatif terhadap kunjungan wisatawan meskipun dampaknya bersifat sementara.

Di Indonesia, penelitian mengenai dampak bencana terhadap kunjungan wisatawan juga sudah beberapa kali diteliti. Salah satunya adalah penelitian yang dilakukan oleh (Mangindaan \& Krityakierne, 2018) yang berjudul Analysis of international visitor arrivals in Bali: modeling and forecasting with seasonality and intervention menghasilkan bahwa bencana dapat berdampak negatif dan signifikan terhadap kunjungan wisatawan mancanegara di Bali. Mereka menggunakan beberapa variabel intervensi seperti Bom Bali I, Wabah SARS, Bom Bali II, Erupsi Gunung Raung dan Erupsi Gunung Rinjani.

Berdasarkan permasalahan di atas, peneliti tertarik untuk menganalisis dampak bencana terhadap kunjungan wisatawan mancanegara ke Bali dan NTB Tahun 2010-2019 untuk mengetahui besar dan lamanya dampak dari bencana tersebut. Analisis ini harapannya dapat memberikan gambaran mengenai fenomena yang terjadi di daerah wisata, mengetahui apakah target yang diharapkan telah tercapai, memudahkan pemerintah mengetahui pencapaian kunjungan wisatawan mancanegara dari tahun ke tahun, membantu pemerintah dan pelaku usaha pariwisata dalam mempertimbangkan mitigasi bencana pada pembangunan objek pariwisata, dan membantu dalam evaluasi kebijakan promosi yang telah dilakukan pemerintah pasca bencana tersebut agar kedepannya lebih baik lagi. 


\section{METODE}

Ruang lingkup dari penelitian ini adalah untuk melakukan analisis intervensi atau dampak dari bencana alam terhadap jumlah kunjungan wisatawan mancanegara menggunakan data time series. Data yang digunakan dalam penelitian ini adalah data jumlah kunjungan wisatawan mancanegara ke Bali dan NTB yang dikumpulkan perbulan dengan periode data dari Januari 2010 hingga Desember 2019 yang diperoleh dari Badan Pusat Statistik dan Dinas Pariwisata Provinsi NTB . Penelitian ini dilakukan untuk menganalisis dampak dari bencana alam yang terjadi di Provinsi Bali dan NTB terhadap kunjungan wisatawan mancanegara di kedua daerah tersebut. Untuk mengetahui dampak bencana tersebut, penelitian ini menggunakan metode ARIMA Intervensi. Variabel yang digunakan dalam penelitian ini ada empat, dengan satu variabel dependen dan tiga variabel intervensi. Variabel dependen yaitu Jumlah Kunjungan wisatawan mancanegara ke Bali dan NTB per bulan, variabel intervensi pertama yaitu erupsi Gunung Rinjani yang terjadi Bulan November 2015, variabel intervensi kedua yaitu erupsi Gunung Agung yang terjadi Bulan November 2017, dan variabel intervensi ketiga adalah Gempa Lombok yang terjadi Bulan Agustus 2018.

Analisis yang digunakan untuk menjawab tujuan dari penelitian ini meliputi analisis deskriptif dan analisis inferensia. Analisis deskriptif digunakan untuk melihat gambaran umum dari variabel yang digunakan guna mendukung analisis inferensia. Pada analisis deskriptif akan dijelaskan dengan menggunakan grafik. Analisis inferensia yang digunakan dalam penelitian ini menggunakan analisis model ARIMA Intervensi Multi Input. Dengan analisis intervensi ini maka akan diketahui apakah bencana meletusnya Gunung Rinjani di Provinsi NTB, Gunung Agung di Provinsi Bali dan Gempa Bumi di Lombok memengaruhi kunjungan wisatawan asing secara signifikan dalam waktu yang singkat atau cukup lama. Selain itu dapat juga diketahui seberapa besar dampak dari kejadian bencana tersebut terhadap jumlah kunjungan wisatawan mancanegara ke Bali dan NTB.

Penulisan model ARIMA intervensi multi input fungsi pulse secara umum dapat dituliskan sebagai berikut (Wei, 2006):

Keterangan:

$$
Y_{t}=f\left(P_{1 t}\right)+f\left(P_{2 t}\right)+f\left(P_{3 t}\right)+N_{t}=\sum_{j=1}^{3} \frac{\omega_{s j}(B) B^{b j}}{\delta_{r j}} I_{j t}+\frac{\theta B}{\phi B} \varepsilon_{t}
$$

$Y_{t}$

: Jumlah Kunjungan Wisatawan Mancanegara ke Bali atau NTB

$f\left(P_{1 t}\right)$ : Fungsi dari variabel intervensi pertama yaitu Erupsi Gunung Rinjani

$f\left(P_{2 t}\right)$ : Fungsi dari variabel intervensi kedua yaitu Erupsi Gunung Agung

$f\left(P_{3 t}\right)$ : Fungsi dari variabel intervensi ketiga yaitu Gempa Lombok

$N_{t} \quad:$ Model ARIMA sebelum intervensi

$I_{j t} \quad$ : Variabel intervensi ke-j pada waktu ke-t ( bernilai 0 untuk sebelum intervensi dan

1 untuk setelah intervensi)

$\omega_{s j} \quad$ : Parameter orde s dengan variabel intervensi ke-j

$\delta_{r j} \quad:$ Parameter orde $r$ dengan variabel intervensi ke-j

$\frac{\theta B}{\phi B} \varepsilon_{t} \quad$ : Model ARIMA sebelum intervensi

$\mathrm{t} \quad$ : waktu (1 s.d 120)

Tahapan pemodelan ARIMA intervensi dijelaskan sebagai berikut (Sohibien, 2018) :

1. Mengelompokkan data menurut waktu terjadinya intervensi dengan rincian sebagai berikut :

a. Data I merupakan data sebelum terjadinya intervensi pertama( Bencana Erupsi Gunung Rinjani), yaitu $t=1,2, \ldots, 70$. Dimulai dari Januari 2000 hingga September $2015\left(n_{1}=\right.$ 70 series data)

b. Data II merupakan data saat intervensi pertama hingga sebelum intervensi kedua(Bencana Erupsi Gunung Agung), yaitu $t=71,71, \ldots, 94$. Dimulai dari November 2015 hingga Oktober $2017\left(\mathrm{n}_{2}=24\right.$ series data)

c. Data III merupakan data pada saat intervensi kedua hingga sebelum intervensi ketiga ( Bencana Gempa Bumi Lombok). Dimulai November 2017 hingga Juli 2018( $\left.n_{2}=9\right)$. 
d. Data IV merupakan data pada saat intervensi ketiga hingga akhir periode penelitian, yaitu $t=104$ s.d 120. Dimulai pada Agustus 2018 hingga Desember 2019 $\left(n_{3}=17\right)$.

2. Menentukan model ARIMA sebelum intervensi menggunakan data sebelum intervensi 1 dengan menggunakan prosedur Box-Jenskin.

3. Lakukan peramalan menggunakan model ARIMA sebelum intervensi yang telah terpilih untuk periode data II dengan data ramalan adalah $\hat{Y}$

4. Hitung nilai residual fit dan ramalan untuk data II.

5. Bentuk plot residual dari data II dengan batas $\pm 2 \hat{\sigma}$

6. Tentukan ordo $b, s$, dan $r$ dari hasil ploting residual.

7. Lakukan estimasi parameter dan uji signifikansi untuk ordo $b, s$, dan $r$ terpilih pada intervensi yang pertama.

8. Lakukan uji diagnostik pada model intervensi yang terbentuk, apakah residualnya sudah white noise dan berdistribusi normal.

9. Apabila langkah ke-8 dan 9 belum terpenuhi, lakukan kembali langkah 6 . Sebaliknya, jika sudah terpenuhi, maka model intervensi pertama sudah terbentuk, dengan pemilihan model terbaik.

10. Selanjutnya, membentuk model intervensi kedua. Lakukan peramalan menggunakan model ARIMA intervensi pertama yang sudah terpilih untuk periode data III.

11. Lakukan kembali langkah 4 hingga 9 menggunakan data III.

12. Model intervensi kedua terbentuk dengan pemilihan model terbaik.

13. Selanjutnya, pembentukan model intervensi ketiga dengan langkah yang sama seperti pembentukan intervensi kedua.

\section{HASIL DAN PEMBAHASAN}

\section{Gambaran Umum Kunjungan Wisatawan Mancanegara}

Kunjungan wisatawan mancanegara memberikan kontribusi yang cukup besar bagi penerimaan negara karena akan meningkatkan sumber penerimaan devisa. Provinsi yang cukup berkontribusi besar dalam hal ini adalah Provinsi Bali dan NTB.

Berdasarkan gambar 1 kunjungan wisatawan mancanegara ke dua provinsi berfluktuasi namun cenderung meningkat. Pada grafik tersebut juga terlihat bahwa terjadi penurunan kunjungan wisatawan mancengara yang cukup drastis baik ke Bali maupun ke NTB. Pada bulan November 2015 terjadi bencana erupsi Gunung Rinjani di NTB. Penurunan kunjungan wisatawan mancanegara ke Provinsi Bali akibat bencana tersebut sebesar 98.512 atau sekitar 26,66 persen, sedangkan untuk Provinsi NTB sebesar 6.047 atau sekitar 8,51 persen. Berselang 2 tahun, tepatnya pada Bulan November 2017, terjadi bencana erupsi Gunung Agung di Bali. Hujan abu vulkanik yang diakibatkan oleh letusan gunung tersebut mengakibatkan penerbangan pesawat ditunda bahkan dibatalkan sehingga beberapa perjalanan dari luar negeri juga terdampak. Sehingga akibat bencana ini, kunjungan wisatawan mancanegara ke Bali turun sebesar 104.079 atau sekitar 22,28 persen dan di Provinsi NTB turun sebesar 37.999 atau sekitar 29,58 persen.

Pada Bulan Agustus 2018, terjadi bencana Gempa Lombok yang juga menyebabkan penurunan baik ke NTB maupun ke Bali. Pada gambar 20 terlihat bahwa di Provinsi NTB penurunan kunjungan wisatawan mancanegara lebih besar jika dibandingkan di Provinsi Bali. Pada awalnya yaitu Bulan Juli 2017 kunjungan wisatawan mancanegara ke NTB sebesar 206.813, namun setelah adanya gempa tersebut kunjungan wisatawan mancanegara turun menjadi 1412 . Sedangkan di Provinsi Bali pada Bulan Juli 2018 kunjungan wisatawan mancanegara sebesar 624.366 dan pada bulan Agustus 2018 turun menjadi 573.766. 


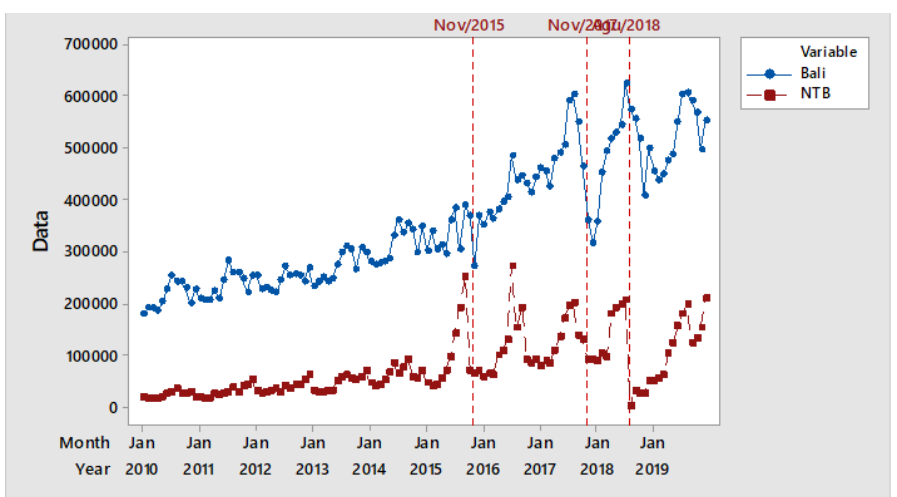

Gambar 1. Kunjungan wisatawan mancanegara bulanan ke Provinsi Bali dan NTB Tahun 2010-2019

\section{Pemodelan ARIMA Intervensi Multi-Input}

Pembentukan model ARIMA sebelum intervensi dilakukan dengan metode Box-Jenkins dengan empat tahap yaitu, Identifikasi, Estimasi, evaluasi dan peramalan. Data Kunjungan Wisatawan Mancanegara sebelum intervensi yaitu data periode Januari 2010 hingga Oktober 2015. Sebelum memasuki tahap identifikasi, data yang diolah harus memenuhi asumsi stasioneritas. Pengecekan stasioneritas dilakukan dengan uji Augmented-Dickey Fuller.

Pada awalnya data jumlah kunjungan wisatawan mancanegara ke Provinsi Bali stasioner pada difference 1, sedangkan NTB stasioner pada level. Kemudian setelah dilakukan estimasi parameter dan cek diagnostik, model yang terbentuk masih belum memenuhi asumsi white noise sehingga diperlukan transformasi data pada jumlah kunjungan wisatawan mancanegara. Tranformasi yang digunakan adalah transformasi logaritma natural. Setelah dilakukan transformasi, selanjutnya kestasioneran data diuji kembali dengan uji ADF dan menghasilkan bahwa data kunjungan wisatawan mancanegara ke provinsi Bali dan NTB stasioner pada difference 1.

Langkah selanjutnya adalah melakukan identifikasi model dengan membentuk model tentatif dari kombinasi ordo AR dan MA pada tingkat difference 1. Untuk data kunjungan wisatawan mancanegara ke Bali, peneliti melihat adanya pola musiman dengan ordo 4. Sedangkan untuk data kunjungan wisatawan mancanegara ke NTB terdapat pola musiman dengan ordo 6 . Selanjutnya, model tentatif yang terbentuk dilakukan estimasi. Model yang terpilih adalah model yang seluruh parameternya signifikan dan memiliki nilai AIC terkecil. Tabel 1 di bawah ini menunjukkan beberapa kombinasi model yang keseluruhan parameter signifikan.

Tabel 1. Model tentatif ARIMA yang terbentuk

\begin{tabular}{cccc}
\hline \multicolumn{2}{c}{ BALI } & \multicolumn{2}{c}{ NTB } \\
\hline ARIMA & AIC & ARIMA & AIC \\
\hline$(1)$ & $(2)$ & $(3)$ & $(4)$ \\
\hline ARIMA $(0,1,1)(2,1,0)^{4}$ & $-146,432$ & ARIMA $(0,1,1)(2,0,0)^{6}$ & 4,8203 \\
ARIMA $(1,1,0)(2,1,0)^{4}$ & -140.275 & ARIMA $(0,1,1)(1,1,1)^{6}$ & 16.51027 \\
ARIMA $(1,1,0)(2,0,0)^{4}$ & -144.72 & ARIMA $(1,1,0)(1,0,1)^{6}$ & 10.9505 \\
\hline Sumber : Hasil Pengolahan & & &
\end{tabular}

Sehingga berdasarkan nilai AIC yang terkecil, model ARIMA sebelum intervensi untuk Provinsi Bali adalah model ARIMA $(0,1,1)(2,1,0)^{4}$ dan Provinsi NTB adalah model ARIMA $(0,1,1)(2,0,0)^{6}$. Selain memiliki nilai AIC terkecil, kedua model tersebut juga telah memenuhi asumsi residual yang berdistribusi normal dan white noise.

\section{Model Intervensi Erupsi Gunung Rinjani}

Intervensi pertama yang digunakan dalam penelitian ini adalah kejadian bencana erupsi Gunung Rinjani NTB yang terjadi pada November 2015, yang merupakan intervensi bentuk fungsi Pulse. Penentuan ordo $b, s$, dan $r$ dilakukan dengan mengidentifikasi plot residual yang melebihi batas $\pm 2 \hat{\sigma}$. Untuk data Provinsi Bali, berdasarkan gambar 5 dan setelah dilakukan trial and error 
didapatkan ordo terbaik yaitu $b=0, s=0$, dan $r=0$. Sedangkan untuk Provinsi NTB didapatkan ordo terbaik yaitu $b=0, s=0, r=1$.

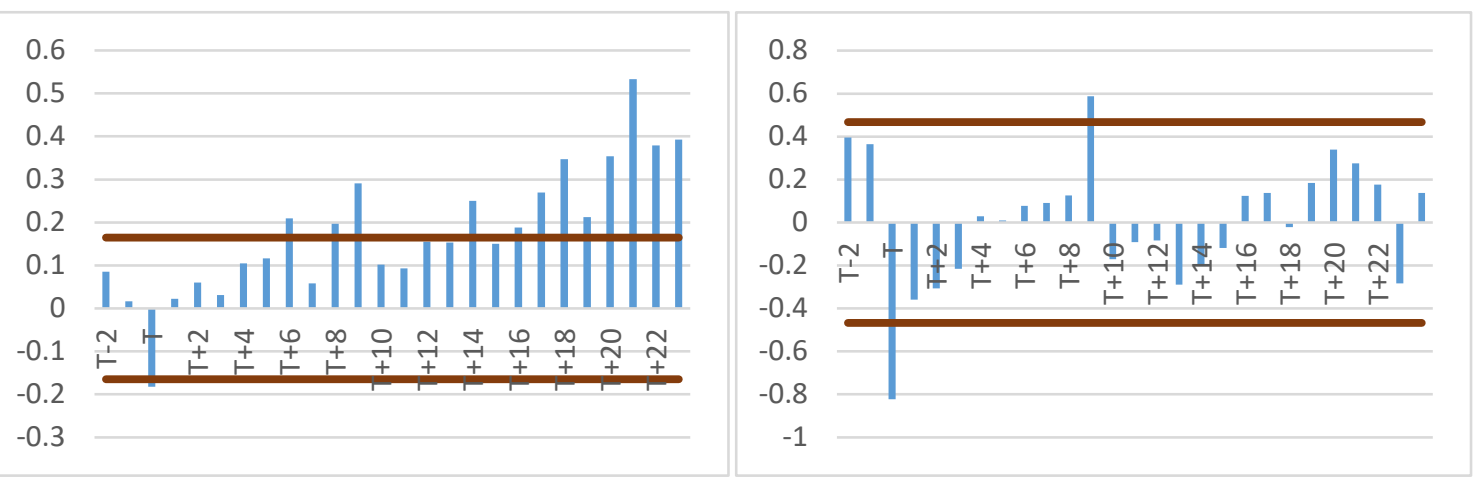

i. Plot Residual

ii. Plot Residual

Gambar 2. Plot Residual (i) Provinsi Bali dan (ii) Provinsi NTB

Selanjutnya dilakukan estimasi parameter pada ordo-ordo yang terbentuk dan menghasilkan nilai yang signifikan, selain itu model juga harus memenuhi asumsi residual white noise dan berdistribusi normal.

Secara matematis model ARIMA intervensi bencana erupsi Gunung Rinjani untuk Provinsi Bali dengan ordo $b=0, s=0, r=0$ dapat ditulis sebagai berikut :

$$
\begin{gathered}
\tilde{Y}_{t}=(-0,20715) B^{0} P_{1 t}+ \\
\frac{(1-0,69579 B)}{\left(1+0,87546 B^{4}+0,83368 B^{8}\right)(1-B)\left(1-B^{4}\right)}
\end{gathered} a_{t}
$$

Sedangkan untuk Provinsi NTB, model ARIMA intervensi bencana erupsi Gunung Rinjani dengan ordo $b=0, s=0, r=1$ dapat ditulis sebagai berikut :

$$
\begin{array}{r}
\tilde{Y}_{t}=\frac{(-0,20715) B^{0}}{1-0,68519 B} P_{1 t}+ \\
\frac{(1-0,47419 B)}{\left(1+0,25615 B^{6}-0,47412 B^{12}\right)(1-B)} a_{t}
\end{array}
$$

Berdasarkan kedua model tersebut, $P_{1 t}$ merupakan fungsi intervensi dari bencana erupsi Gunung Rinjani NTB yang terjadi pada Bulan November 2015.

Kedua model juga memiliki parameter $\omega_{0}$ yang signifikan pada alfa 5 persen dan bernilai negatif yang menunjukkan bahwa dampak dari kejadian erupsi Gunung Rinjani menyebabkan penurunan kunjungan wisatawan mancanegara baik ke Bali maupun NTB. Nilai ordo parameter $\omega_{0}$ adalah 0, yang berarti bahwa dampak dari terjadinya erupsi Gunung Rinjani adalah langsung. Pada Provinsi Bali ordo $s=0$ yang menunjukkan bahwa dampak erupsi Gunung Rinjani hanya dirasakan saat bulan terjadinya erupsi. Artinya, pada Bulan Desember 2015 jumlah kunjungan wisatawan mancanegara sudah kembali normal. Namun, untuk Provinsi NTB, kunjungan wisatawan mancanegara ke Provinsi NTB memiliki efek gradual yang ditunjukan dengan ordo $r$ bernilai 1.

\section{Model Intervensi Erupsi Gunung Agung}

Intervensi kedua pada penelitian ini adalah kejadian bencana erupsi Gunung Agung yang terjadi pada Bulan November 2017. Untuk wilayah Provinsi Bali, ordo yang diduga berpengaruh signifikan adalah $b=0, s=3, r=0$. Sedangkan untuk Provinsi NTB, gambar 2 menunjukkan bahwa tidak ada nilai residual yang melewati batas. Sehingga dimungkinkan bahwa tidak ada ordo b,s dan $r$ yang signifikan. 


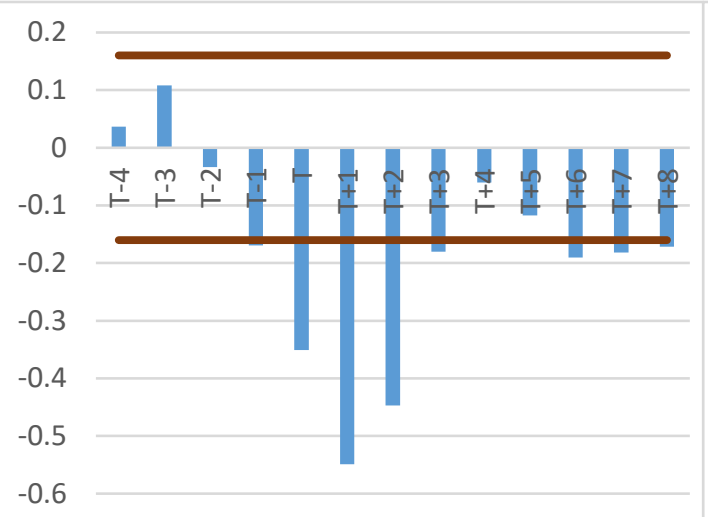

i. $\quad$ Plot Residual

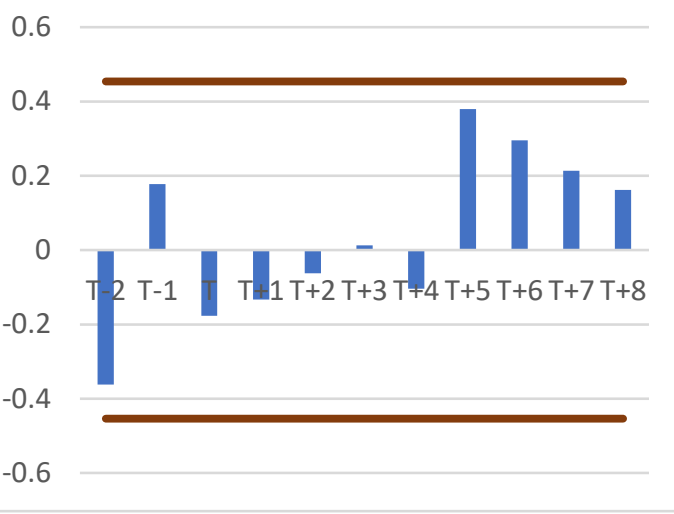

ii. Plot Residual NTB

Gambar 3. Plot Residual (i) Provinsi Bali dan (ii) Provinsi NTB

Selanjutnya dilakukan estimasi parameter pada ordo-ordo yang mungkin dan setelah trial and error didapatkan ordo yang signifikan dan terbaik adalah $b=0, s=1, r=1$. Secara matematis model ARIMA intervensi kedua akibat erupsi Gunung Agung untuk Provinsi Bali dapat ditulis sebagai berikut:

$$
\begin{gathered}
\tilde{Y}_{t}=(-0,20819) \mathrm{B}^{0} P_{1 t}+\frac{(-0,33686-0,34922 B) B^{0}}{1-0,68519 B} P_{2 t}+ \\
\frac{(1-0,69474 B)}{\left(1+0,89827 B^{4}+0,81744 B^{8}\right)(1-B)\left(1-B^{4}\right)} a_{t} \ldots . .(4)
\end{gathered}
$$

Pada model di atas $P_{2 t}$ merupakan fungsi intervensi dari kejadian bencana erupsi Gunung Agung yang terjadi Bulan November 2015. Parameter $\omega_{02}$ bernilai negatif yang menunjukkan bahwa dampak dari kejadian tersebut menyebabkan penurunan kunjungan wisatawan mancanegara ke Bali. Nilai ordo dari parameter tersebut adalah 0 , yang berarti bahwa dampaknya bersifat langsung. Dampak tersebut berlangsung selama satu bulan setelah dampak pertama kali dirasakan yang dapat dibuktikan dengan ordo $s$ bernilai 1 . Penurunan jumlah kunjungan wisatawan mancanegara ke Provinsi Bali ini tentu saja karena banyak penerbangan yang batal akibat penutupan Bandara Ngurah Rai (Gamar, 2017). Penutupan ini disebabkan karena hujan abu vulkanik yang dapat mengganggu penerbangan. Selain itu, beberapa negara menerapkan travel advice atau imbauan kepada warga negara agar berhati-hati untuk melakukan kunjungan ke Indonesia. Negara-negara itu adalah Singapura, Australia, Inggris, Selandia Baru, dan Irlandia (Hikmah, 2017). Selain itu, Negara China menerapkan travel warning yaitu larangan untuk berkunjung ke Indonesia (Kurniawan, 2018).

Berbeda dengan Provinsi Bali, Model Intervensi kedua untuk Provinsi NTB tidak ada satupun parameter yang signifikan. Sehingga model intervensi pertama untuk Provinsi NTB berubah. Secara matematis model ARIMA intervensi pertama akibat erupsi Gunung Rinjani untuk Provinsi NTB setelah perubahan dapat ditulis sebagai berikut :

$$
\begin{array}{r}
\tilde{Y}_{t}=\frac{-0,31367 B^{0}}{1-0,68227 B} P_{1 t}+ \\
\frac{(1-0,49100 B)}{\left(1+0,26382 B^{6}-0,49285 B^{12}\right)(1-B)} a_{t} \ldots \ldots \ldots \ldots \ldots \ldots \ldots \ldots \ldots \ldots \ldots \ldots \ldots \ldots
\end{array}
$$

Dari pengujian kedua model di atas, menunjukkan bahwa terdapat perbedaan dampak erupsi Gunung Agung November 2017 terhadap kunjungan wisatawan mancanegara antara Provinsi Bali dan Provinsi NTB. Erupsi Gunung Agung 2017 berdampak pada kunjungan wisatawan mancanegara ke Bali secara signifikan, sedangkan bencana tersebut tidak berdampak terhadap kunjungan wisatawan mancanegara ke Provinsi NTB. Faktor utama perbedaan hasil ini tentu karena lokasi Gunung Agung yang terletak di Provinsi Bali, sehingga wisatawan mancanegara yang berkunjung ke NTB tidak terlalu berdampak. Selain itu, Dinas Kebudayaan dan Pariwisata NTB sendiri sudah menyiapkan antisipasi dari dampak erupsi. Antisipasi ini dibagi menjadi tiga tahap pengelolaan mitigasi krisis pariwisata, yang pertama adalah Tahap tanggap darurat, yang kedua adalah tahap rehabilitasi, dan yang terakhir adalah tahap normalisasi (Dinas Kebudayaan dan 
Pariwisata, 2017). Faktor lain adalah penutupan Bandara International Lombok tidak selama yang dilakukan di Bali. Sehingga penerbangan yang batal tidak begitu banyak.

\section{Model Intervensi Gempa Lombok}

Intervensi yang terakhir pada penelitian ini adalah terjadinya bencana Gempa Lombok yang terjadi pada 5 Agustus 2018. Berdasarkan gambar 26 dan dilakukan trial and error untuk untuk mendapatkan model yang terbaik, model intervensi ketiga yang terbaik dan telah memenuhi asumsi untuk Provinsi Bali memiliki ordo $b=3, s=0$, dan $r=1$ dan untuk Provinsi NTB memiliki ordo $b=0, s=1,2 r=1$.

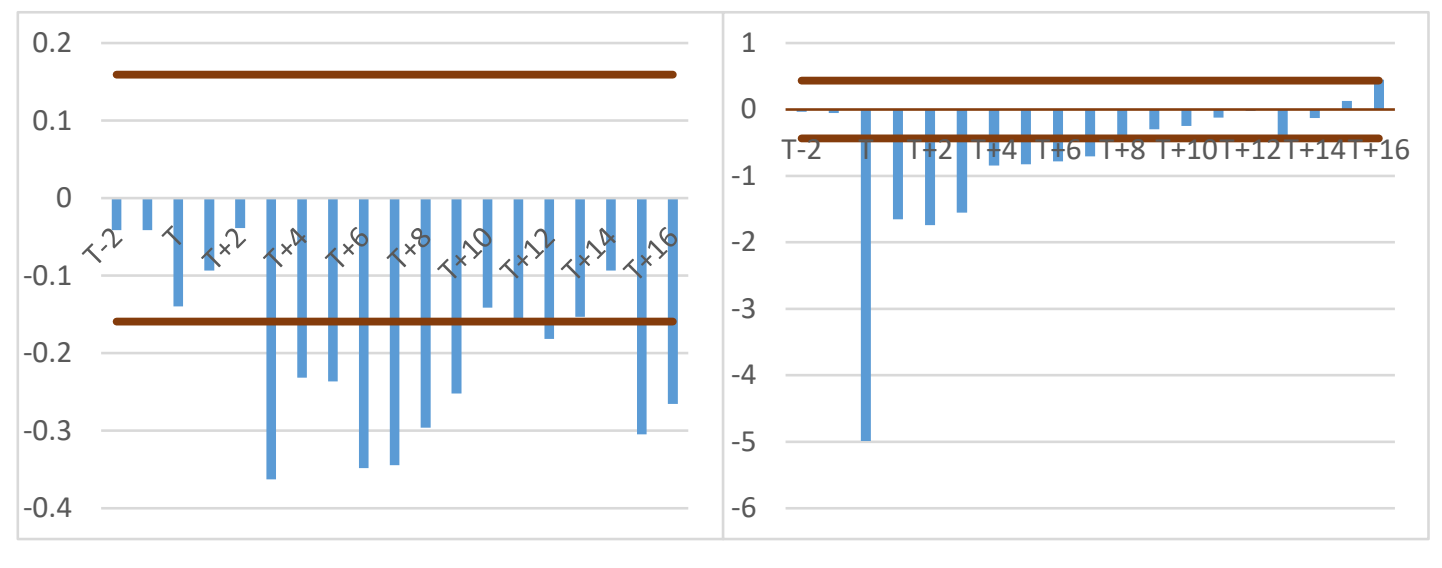

i. Plot

ii. Plot

Gambar 4. Plot Residual (i) Provinsi Bali dan (ii) Provinsi NTB

Selanjutnya dari ordo-ordo yang terbentuk dilakukan estimasi parameter. Sehingga model intervensi ketiga Provinsi Bali dapat ditulis sebagai berikut:

$$
\begin{aligned}
& \tilde{Y}_{t}=(-0,20602) B^{0} P_{1 t}+\frac{(-0,27233-0,42097 B) B^{0}}{1-0,48835 B} P_{2 t}+\frac{(-0,16763) B^{3}}{1-0,88354 B} P_{3 t}+ \\
& \frac{(1-0,64350 B)}{\left(1+0,89246 B^{4}+0,81994 B^{8}\right)(1-B)\left(1-B^{4}\right)} a_{t}
\end{aligned}
$$

Sedangkan untuk Provinsi NTB dapat ditulis sebagai berikut :

$$
\begin{gathered}
\tilde{Y}_{t}=\frac{-0,31440 B^{0}}{1-0,70851 B} P_{1 t}+\frac{\left(-5,05995+2,68408 B-0,4780 B^{2}\right) B^{0}}{1-0,83708 B} P_{3 t}+ \\
\frac{(1-0,50195 B)}{\left(1+0,21369 B^{6}-0,53209 B^{12}\right)(1-B)} a_{t} \ldots .(7)
\end{gathered}
$$

Berdasarkan kedua model di atas, $P_{3 t}$ merupakan fungsi intervensi dari kejadian bencana Gempa Lombok yang terjadi pada Agustus 2018. Model intervensi ketiga Provinsi Bali dan NTB memiliki parameter $\omega_{03}$ yang signifikan pada alfa 5 persen dan bernilai negatif, yang menunjukkan bahwa gempa menyebabkan penurunan kunjungan wisatawan mancanegara. Nilai ordo dari parameter model Bali adalah 3, yang berarti bahwa dampak dari terjadinya gempa Lombok dirasakan pertama kali pada bulan ketiga setelah kejadian, sementara ordo parameter model NTB adalah nol yang berarti bahwa dampak tersebut langsung.

Selanjutnya ordo $r$ model Bali bernilai 1 menunjukkan bahwa tedapat pola gradual pada residual setelah ordo $b+s$. Untuk Provinsi NTB orde $s$ bernilai 2 , artinya dampak tersebut berlangsung selama dua bulan dan setelah itu terdapat pola gradual yang dibuktikan dengan ordo $r=1$.

Pengujian kedua model di atas memberikan hasil bahwa dampak bencana Gempa Lombok menyebabkan kunjungan wisatawan mancanegara ke Provinsi Bali dan NTB mengalami penurunan. Namun, keduanya memiliki respon kejadian yang berbeda. Dampak yang dirasakan akibat bencanca Gempa Lombok di Provinsi Bali terdapat jeda 3 bulan, sedangkan dampak langsung untuk Provinsi NTB. 


\section{Besar Dampak Intervensi}

Pada analisis sebelumnya, dijelaskan bahwa data yang digunakan merupakan bentuk transformasi. Sehingga untuk menghitung dampak harus dilakukan invert atau mengembalikan ke bentuk sebelum transformasi. Mula-mula dilakukan peramalan dari model intervensi pertama, selanjutnya hasil dari peramalan dilakukan invert, setelah itu mengurangkan hasil ramalan dari model intervensi dengan model sebelum intervensi.

Penurunan akibat bencana erupsi Gunung Rinjani di Bali sebesar 60.397 atau sekitar 18,55 persen yang terjadi Bulan November 2015 dan pada bulan selanjutnya sudah terjadi peningkatan sebesar 0,35 persen. Sementara itu, untuk Provinsi NTB penurunan jumlah kunjungan wisatawan mancanegara pada Bulan November 2015 sebesar 22.495 atau sekitar 24,18 persen dan penurunanan terus terjadi hingga Bulan Maret 2016.

Dampak terjadinya erupsi Gunung Agung di Provinsi Bali mulai terjadi pada Bulan November 2017 yaitu sebesar 148.907 atau sekitar 29,04 persen. Selanjutnya pada Bulan Desember 2017, penurunan semakin besar mencapai 42,74 persen, lalu pada bulan selanjutnya persentase penurunan berangsur-angsur berkurang hingga pada Bulan Juli 2018 penurunan hanya sebesar 5,26 persen.

Gempa Lombok menyebabkan kunjungan wisatawan mancanegara ke Provinsi Bali turun sebesar 144.569 atau sekitar 24,72 persen yang terjadi Bulan November 2018. Selanjutnya penurunan jumlah kunjungan wisatawan mancanegara ini terus berlangsung dan fluktuatif, hingga Bulan Desember 2019. Sementara itu, bencana Gempa Lombok menyebabkan kunjungan wisatawan mancanegara Provinsi NTB turun sebesar 206.347 atau sekitar 99,36 persen. Penurunanan dimulai Bulan Agustus 2018 dan pada bulan selanjutnya berfluktuatif namun cenderung semakin berkurang, hingga pada Desember 2019 kunjungan wisatawan mancanegara ke NTB mulai mengalami peningkatan sebesar 27,55 persen.

\section{KESIMPULAN}

Perkembangan jumlah kunjungan wisatawan macanegara periode 2010-2019 di Provinsi Bali dan NTB secara umum mengalami fluktuasi namun menunjukkan trend yang cenderung meningkat. Adanya bencana erupsi Gunung Rinjani 2015, Erupsi Gunung Agung 2017, dan Gempa Lombok 2018 menyebabkan penurunan kunjungan wisatawan mancanegara yang cukup drastis. Erupsi Gunung Rinjani berdampak signifikan terhadap penurunan jumlah kunjungan wisatawan mancanegara baik ke Bali maupun ke NTB. Dampak erupsi Gunung Rinjani lebih besar dirasakan pada lokasi bencana, dengan persentase dampak sebesar 24,18 persen untuk Provinsi NTB dan 18,55 persen untuk Provinsi Bali. Erupsi Gunung Agung signifikan menurunkan jumlah kunjungan wisatawan mancanegara ke Bali. Dampak pertama kali dirasakan pada bulan bencana, yaitu pada Bulan November 2017 sebesar 29,04 persen dan pada Bulan Desember 2017 yaitu sebesar 42,74 persen. Sementara untuk Provinsi NTB, erupsi Gunung Agung tidak berdampak signifikan pada kunjungan wisatawan mancanegara. Gempa Lombok signifikan menurunankan jumlah kunjungan wisatawan mancanegara baik ke Bali maupun ke NTB. Penurunan pada Provinsi Bali pertama kali dirasakan setelah 3 bulan bencana terjadi, yaitu pada Bulan November 2018 sebesar 24,72 persen. Pada Provinsi NTB, dampak bencana gempa Lombok pertama kali dirasakan pada bulan terjadinya gempa, yaitu pada Bulan Agustus 2018 sebesar 99,36 persen.

\section{DAFTAR PUSTAKA}

Agmasari, S. (2016). Sembilan Destinasi Indonesia Dapat Penghargaan Trip Advisor. Travel Kompas. https://travel.kompas.com/read/2016/09/07/200300727/sembilan.destinasi.indonesia.dapat.pengharga an.tripadvisor

Dinas Kebudayaan dan Pariwisata. (2017). Antisipasi Dampak Erupsi Gunung Agung Bersama Deputi Pengembangan Pemasaran Pariwisata Mancanegara. Dinas Kebudayaan Dan Pariwisata. https://www.disbudpar.ntbprov.go.id/antisipasi-dampak-erupsi-gunung-agung-bersama-deputipengembangan-pemasaran-pariwisata-mancanegara/

Gamar, R. (2017). Penutupan Bandara Ngurah Rai Kembali Diperpanjang hingga Kamis Pagi. Regional Kompas. https://regional.kompas.com/read/2017/11/29/06350611/penutupan-bandara-ngurah-raikembali-diperpanjang-hingga-kamis-pagi 
Hikmah, N. (2017). Gunung Agung Meletus, 5 Negara Keluarkan Travel Advice. Okenews. https://news.okezone.com/read/2017/11/24/340/1820061/gunung-agungmeletus-5-negara-keluarkantravel-advice-ke-bali\%0D

Huang, J.-H., \& Min, J. C. H. (2002). Earthquake devastation and recovery in tourism: the Taiwan case. Tourism Management, 23(2), 145-154.

Hulwa, A. . (2018). Indonesia Bertengger di Peringkat ke-7 Pariwisata Terbaik Dunia. Detik Travel. https://travel.detik.com/travel-news/d-4275139/indonesia-bertengger-di-peringkat-ke-7-pariwisataterbaik-dunia

Iman, R. . (2019). BMKG Ingatkan Ancaman Megathrust. Republika Nasional.

Kurniawan, H. (2018). Ini Dia Deretan Travel Advices yang Mencekik Kunjungan Wisman. Merdeka. https://www.merdeka.com/gaya/ini-dia-deretan-travel-advices-yangmencekik-kunjunganwisman.html\%0D

Mangindaan, J. M. P., \& Krityakierne, T. (2018). Analysis of international visitor arrivals in Bali: Modeling and forecasting with seasonality and intervention. Journal of Physics: Conference Series, 1132(1). https://doi.org/10.1088/1742-6596/1132/1/012069

Sohibien, G. P. D. (2018). Analysis of the effect of fuel price policy on Jakarta inflation by using multi-input intervention model. AIP Conference Proceedings, 2014(1), 20125.

Sudarmo, S. N. (2005). A community-based approach to tourism in Indonesia. Victoria University of Technology.

Wu, L., \& Hayashi, H. (2014). The impact of disasters on Japan's inbound tourism demand. Journal of Disaster Research, 9(sp), 699-708. 